\title{
Religious pluralism and its implications for church development
}

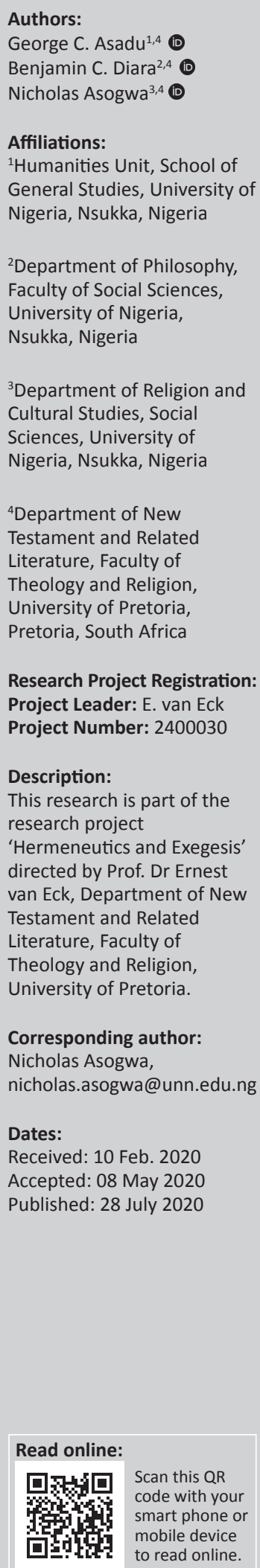

Religious pluralism model holds the belief that there is virtue in every religion, just as all religions are good and are of equal value. It does not consider religion's particularity but is interested in the ideas that have not favoured any religion. The issue with this concept is not its assertion of the validity of all religions. It is rather with its denial of the finality of any religion as the way by which people could come to God. Hence, it allows the existence of multiple religions in a given society and encourages religious tolerance. The beauty of pluralism is its flexibility which makes religious practicing a wilful act and religious conversion a choice and not a force, although it has the tendency to encourage syncretism. This research examines critically the implications of pluralism using historical approach on the development of Christian church. Data for the research were basically obtained from secondary sources. The findings reveal that although religious pluralism has its negative sides, it gives the much needed boost to development of church if its tenets are followed. Accordingly, the article recommends that Christian churches in pluralist societies such as Nigeria should imbibe the virtues of religious tolerance, and dialogue, if they want to remain alive and continue to be relevant.

Contribution: Religious pluralism is a panacea to inordinate and incessant religious conflict, if given its proper place in Nigeria, will breed religious tolerance, peace and progress. This work would be of immense of benefit to government, missionaries and students across all strata of discipline.

Keywords: religion; pluralism; church; development; religious dialogue.

\section{Introduction}

Nigeria is a part of African entity which Mbiti (1969) has described as being notoriously religious. Although Africa, in general, is a very cultural and ethnically diverse society, its religion was able to bind them together by providing both ethnic and domestic harmony. There was no rigidity of identity in Nigeria as it is found today mainly because they had similar philosophical and religious worldview. According to Ugwu and Ugwueye (2004):

$[T]$ he religion is traditional, in the sense that it is an aboriginal and fundamental thing, which is handed, down from generation to generation and is still practised by living people today. (p. 6)

\section{Onunwa (1990) remarked that:}

$[T]$ he traditional religion is indeed society itself and there is no clear demarcation between the sacred and the profane. Both the spiritual and the physical realms of the universe are believed to work in a consistent harmony and are subject[ed] to an ordered system and rhythm. (p. 80)

Buttressing this point, Asadu (2015) has highlighted the importance of traditional religion to Africans; thus Asadu (2015):

Their religion is intertwined with their culture; so serious, so important that it is indispensable in their daily life and every human activity revolved around God. To them the religion is not optional but a tradition. Once a child is born, he or she becomes an adherent, and thus it is firmly internalised. (p. 50)

Unfortunately, with the advent of Christianity and Islam, the African Traditional Religion which was the harnessing equipment that had held people together was attacked and dismantled by the foreign influence.

Thenceforth, their moral laws and ethical values were rebranded; although they were equivalent to their original traditional laws, they were confusing as it has been influenced by the foreign elements. Thus, all those rebranded laws are still dangling from papers but have not much consequence as the

How to cite this article: Asadu, G.C., Diara, B.C. \& Asogwa, N., 2020, 'Religious pluralism and its implications for church development', HTS Teologiese Studies/Theological Studies 76(3), a5955. https://doi.org/10.4102/hts.v76i3.5955

Copyright: @ 2020. The Authors. Licensee: AOSIS. This work is licensed under the Creative Commons Attribution License. 
traditional means of social control had on the people. Hence, people commit all sorts of atrocities with impunity.

The matter was exacerbated by the partitioning and occupation of African space by Europeans in 1884-1885. This act dismembered some people from their ancestral roots and unfairly got them merged with other ethnic groups to form a sovereign state. Thus, Nigeria came into existence in 1914. It would be no exaggeration, therefore, to say that even before independence in 1960, Nigerians were already divided in three religious affiliations.

Although the divisions were suppressed by the influence of colonial masters, the ethnic and religious differences continued to manifest itself in all shares of nationhood and eventually worsen the political situation, which led to the fall of first republic. The Europeans were interested in occupying the land, whilst the religious propagandists were more interested in the number of converts that they almost failed in their duty to educate their adherents the commandment of God, in which the cardinal religious point 'love for God and ones neighbour' is contained. As consequences, there were divisions, confusions, crises and underdevelopment that are now rocking Africa, particularly Nigeria 'the giant of Africa'.

\section{Clarification of concepts Pluralism and religious pluralism}

Ordinarily and descriptively, religious pluralism refers to the existence of multiple religions in a given environment. However, as a model, religious pluralism equals the belief of coexistence of multiple religions in a society, wherein each religion is accepted as legitimate and is provided equal opportunity to flourish without any form of inducement or prejudice in favour or against anyone of them by the government (Got Questions 2020):

$[M]$ ore than mere tolerance, religious pluralism accepts multiple paths to God or gods as a possibility and is usually contrasted with 'exclusivism', the idea that there is only one true religion or way to know God. (p. 1)

Objantoro (2018:2) defines religious pluralism as 'existential acceptance of the other as the other, that is, without being able to understand or to co-opt him'. Religious pluralism portrays the view that all religions are valid or genuine in their respective ways of beliefs, worships and practices, irrespective of independence and radical differences. Put differently, within the framework of pluralism, there is no superior religion, as all religions are considered to be equal. It is in the light of this observation and given the level of religious intolerance in Nigeria that Diana (2007) remarks on religious pluralism become apt. In his words, ' ... Religious pluralism is a critical theological issue for people of faith, raising fundamental questions about one's own faith in relation to the religious other' (Diana 2007:743). From what has been said so far, religious pluralism could be correctly said to be synonymous with the acceptance of all other religions as enjoying equal existential, operational and methodological validity and genuineness as one's own religion. This, we think, is what Objantoro (2018) meant when he says that:

$[P]$ luralism is humble, only knows that I or we may not possess the whole truth and does not pass judgment as to whether the other may also be right or, as it may turn out, wrong. (p. 2)

Reasonable as this conception might be, it raises a fundamental problematic issue, if accepted. This issue has to do with the question of how do we assess or compare one religion with the others if, in reality, religious pluralism means that no one religion is superior to or more genuine than the other? In other words, religious pluralism, similar to all other brands of pluralism, raises the problem of 'appraisal mechanism'. For instance, in country such as Nigeria, the acceptance of religious pluralism implies, amongst other things, that (1) neither Christ nor Mohammed is the only saviour of human race; (2) belief in Christ or Mohammed and commitment to their various ways guarantee salvation in no less measure. It therefore becomes worrisome when many religious adherents in Nigeria claim to embrace religious pluralism, but fan the embers of religious violence by way of their fundamentalist dispositions.

It is worthy to note here that the foremost weapon in the hands of the advocates of religious pluralism and the consequential truths is the existence of plural societies with multireligious-cum-cultural practices. All these notwithstanding, the begging question remains: Can it not be the case that one religion may be better than the other? John Hick and Paul Knitter are amongst the known ardent defenders of religious pluralism. In one of his popular articles entitled: 'The Next Step beyond Dialogue', Hick (2005) wrote the following:

\footnotetext{
... here we are in the West with the prevailing understanding of the religions as bounded entities existing over against one another. Seen in this way, each is a unique totality of forms of spiritual practice, revered scriptures, treasured creeds, stories and myths, familiar symbols, systems of doctrine, moral codes, great paradigmatic figures, remembered histories, cultural ethos, authority figures. (p. 6)
}

In the light of these observations, Hick (2005) is of the view that the pluralists would consider it a fundamental mistake to elevate any one of them - always of course one's own - as uniquely superior to all the others. His argument is that in the vast majority of cases, we inherit our religion along with our nationality, our language and our culture. In a similar vein, he opines that the religion to which anyone subscribes as well as the religion against which anyone reacts and which they reject - depends in the vast majority of cases on where they were born. Hick (2005) is well aware that one of the natural consequences of religious pluralism is religious or inter-faith dialogue. He sees inter-faith dialogue as a mechanism adopted by agents of religion in a multi-religious society, whereby those dialoguing have it (as a belief) at the back of their minds and usually without saying it aloud that theirs is really the one and only true or fully true faith. The aim here, according to Hick (2005), is:

$[T]$ o dialogue between people who accept the genuine religious equality of the other, so that they can then benefit freely from 
another's distinctive spiritual insights and be free to join together in facing the massive social and economic and political problems of the world. (p. 3).

In endorsing the pluralist model, Hick (2005) submits that:

$[T]$ he variety around the world of our different ways of being human, which are the great cultures and religions of the earth, is something to celebrate and understand, not something to try to iron out. (p. 3)

Like Hick, Knitter (ed. 2005) is himself an advocate of religious pluralism. He, however, condemns in strong terms any attempt by any person to hide under the cloak of religious autonomy and perpetrate violence. Hence, he encourages religious dialogue. Seshagiri (2005) is another strong advocate and defender of pluralist model. For him, in a plural society, the pluralist model becomes necessary as a mechanism for 'making sense of the incorrigible reality of religious diversity'. He considers religious dialogue a sine qua non in a multi-religious society. In his thinking, religious dialogue as a mechanism follows from the realisation that ignorance about the faiths of other people gives rise to prejudices and misrepresentations, which, in turn, results in the unwillingness to accept the integrity of the followers of other traditions. In a related development, Seshagiri (2005:n.p) correctly observes that 'it is lack of sensitive understanding of others' faith that has often led to mutual recrimination and bloodshed. People quarrel about religions only when they lose sight of the human dimension of religions'. He points out that it is on the basis of the preceding observations that Mahatma Gandhi, an advocate of the pluralist model, believed that education without the study of religions is incomplete.

Buttressing this point, Idowu (2009) echoes the opinion and stance of the above-mentioned scholars when he states that:

$[R]$ eligious pluralism is a situation where people of different religions and faith live together and interact at all levels without fear or prejudice. It is an attitude or policy regarding the diversity of religious belief systems co-existing in society. (p. 8)

According to Domenic (2007), 'Pluralism is basically the belief that the world religions are true and equally valid in their communication of the truth about God, the world and salvation'. In support of his observations, Domenic (2007) copiously quoted John Hick, whom he wrongly claimed to be the propounder of religious pluralism. He, however, got it correct when he says that as a pluralist, Hick does not consider Christianity to be the absolute, unique and final way to God. Pluralism demands that all religions should be given equal recognition. In addition, as Harris (2005) rightly observed:

[T] he idea that any one of our religions represents the infallible word of the One True God requires an encyclopaedic ignorance of history, mythology, and art even to be entertained-as the beliefs, rituals, and iconography of each of our religions attest to centuries of cross-pollination among them. (p. 3)

It is on the basis of the above that Harris (2005:5) calls for religious moderation, arguing that it seems a reasonable position to stake out in the light of all that we have (and have not) learned about the universe', not minding that 'it offers no bulwark against religious extremism and religious violence'. Harris (2005) was correct to have observed that good as religious pluralism might be, it is not acceptable to all. In other words, it has its own critics. According to Deshpande (2018:n.p):

[C]ritics state that in the bargain of accepting all religions as equal, one tends to lose the real essence and meaning of his/her own religion. Religious faith ultimately remains a personal affair, though it can be hugely influenced by society.

Whilst religious pluralism has been in existence since at least the 17th century, the concept has become more popular since the latter half of the 20th century in Western Europe and North America.

Specifically, the idea of religious ecumenism (religions working together as one) and the recently popularised interfaith movement have led to the increased acceptance of religious pluralism in popular culture (Got Questions 2020). Migration of people from various parts of globe, particularly from non-developed countries to the USA has made the USA a pluralistic society. In a country with such great socio-political and religio-cultural diversities, harmonious coexistence might be difficult without a fair positive outlook and radical thought process that advocates freedom. Therefore, it is not surprising that religious pluralism in the USA took place gradually. Currently, all religions benefit from the same legal protections and are free to express their views. By the provision of law, these immigrants in the USA have continued to follow their own faith systems.

Going by the law in most of the circular states, including Nigeria, all religions are benefitted from the same legal protections and are free to express their views. Contemporarily, much theoretical work rests on what the diversity of the US society means for the concept of civil religion. The US religion has seen increasing pluralism regarding ideology, faith tradition, practice and increasing amount of secularism and lack of religiosity. In the USA, many religions (and denominations within religions) are practiced side by side. According to the law, all religions are benefitted from the same legal protections and are free to express their views.

\section{Religion}

The ultimate purpose of religion includes helping humans to know themselves, their origin, nature and purpose of life; to bring them into a relationship with the transcendent; to instil peace in a troubled heart and to unite people together in worship and service. Thus, people of different origins who might previously been at war with one another has through religion been fastened together. Anyacho (2005) admitted this fact when he gave the root meaning of religion as derived from the Latin word Religio, meaning to hold together; he therefore concluded that:

$[I] \mathrm{t}$ represents the coming together of a group which is bound by a common feeling of dependence on a particular object or subjects believed to be more powerful than man. (p. 1) 
Commenting on the importance of religion, Onyeidu (1999:6) averred that 'while man engages in religious activity, religion in turn helps to make man there is therefore, no gain saying the fact that religion contains a system of values'. According to (Onyeidu 1999:6), these values are appreciated in 'the ethical dos and don'ts' of religion. Indeed, the duty to provide these ethical laws for people is one of the noble tasks of religion everywhere in the world. In agreement with this fact, Ireoba (2008) averred that:

$[R]$ eligion meets human needs. It gives to man what he cannot obtain from any other source namely, a confidence in the outcome of life's struggles through a personal connection with the superior powers in the world. (p. 7)

Hence, religion is indispensable for the human society.

Undoubtedly, religion has shaped human life and on that note, religions are generally believed to be good and the same. However, considering the sameness, some people still feel that some religions are more developed than the others. For those who hold such an opinion, this could be adduced from doctrines and traditions, theology and liturgy of different religions. Be that as it may, we consider it an error of thought borne out of ignorance to assert that one religion is more developed than the other without providing any standard or objective parameter for carrying out the appraisal. To say that one religion is more developed than the others is the same as saying that one religion has better promise of eternity or seeing God than the others.

Certainly, Christianity and Islam are easily accessible through their holy books and other religious documents such as commentaries, magazines, liturgy, catechism handbooks, cannons and so on, but it does not seem to us that being better documented in their activities makes them being more developed than other religions. If we may ask, is it the case that the countries with written constitution are more developed than the countries with unwritten constitution?

\section{Church development}

Church in the New Testament has two words derived from the Septuagint for church, ekklesia from ek and kaleo 'to call out' and 'synagogue', from sun and ago, meaning 'to call or bring together'. The latter is used extensively to denote either the religious gathering of the Jews or the buildings in which they assembled for public worship. The term ekklesia, however, generally designates the church of the New Testament, although at few places it denotes common civil assemblies (Berkhof 1958:556-557). The Greek word ecclesia refers to any assembly, it could be local congregation of believers or the universal body of all believers, and hence the statement 'where two or three are gathered in my name I (Christ) am in their midst' (Mt 18: 20).

The word 'development', according to the Oxford English Dictionary (1995) means, 'to grow or cause something to grow gradually'. Growth is a phenomenon in the life of an object, it is measured by the increase it has recorded over time; it could be in number, size, power or intensity (Asadu 2015). On the other hand, Church Development, which has become a household word in the Christendom today, is an integral concept embracing all aspects of life in the church. A church's level of development could be judged from the numerical increase, economic viability, infrastructural development, high-quality administration and spiritual status of the church (Asadu 2015).

Above all, the individual development of church's members is paramount, for it is the individual that makes up the church. Therefore, a holistic development is tantamount to the development of the body of Christ as a whole. Obviously, church begins with people and continues to focus on the general development of the people.

Hence, every other church project revolves around human development. It is instructive to note that church development we have in mind here is mainly with reference to Christian church(es) in Nigeria.

Thus, the first sign of church growth is the numerical increase of faithful members who earnestly understand the purpose of church and genuinely adhere to its doctrine. Their faith is measured by their works, which include their loyalty and dedication to church, zeal for its mission or evangelism and commitment to its social service. The effort to erect an edifice where people could gather for worship is a primary response to congregational need.

The purpose of evangelical outreach is all about increase and expansion. Converts are trained to make more disciples; thus, there is large followership. Infrastructure helps the working of church effectively. Through dedication, commitment and diligence, church transforms the society. This suffices that church development is achieved through a remarkable chain of events that impacts the society. Although church is a community development, its impartation in a society depends on the nature of its environment.

Church performs better and grows fast in an environment where there is freedom to worship. Onyeidu (1999:21) corroborated this fact when he averred 'the power of religion to perform its function in any society depends on the type of society and the place of religion in it'. For instance, in a society where the church is politically disadvantaged and is in serious persecution, its achievements might not commensurate with its efforts.

In other words, church's input could be high but the output might become low. The constant killings of Christians with impunity and the wanton destruction of church's properties at any crisis are a setback to church development.

It was very difficult for church to develop in the Roman world until 313 AD, when the Edict of Milan was enacted. The Edict made Christianity a 'religio licita', which gave Christianity equal recognition as the Heathen worship. 
According to Boer (1976:105), the Edict of Milan 'gave the church freedom of worship and returned to her all properties that had been confiscated'. There is no gainsaying the fact that development of church was made easy through a number of factors - firstly being the freedom of worship, which provides conducive environment by proper disciplining.

\section{Dysfunction of religion}

In spite of the noble unifying role of religion in human society, it is also dysfunctional in nature and has played a divisive role in the world. That is what Ireoba (2008) referred to as another side of religion. This other side of religion 'makes negative recreations, which make religion part of man's problem instead of solution' (Ireoba 2008:8). According to Asadu (2018):

Religion is a functional uniting factor in places where there is a state religion but is dysfunctional in secular states where there is multiple religious sects. Therefore, in a multi-ethnic society like Nigeria with marked plurality of religious views among the citizens there is the inevitability of clash. Of course, the country has been ravaged by ethno-religious conflict. (p. 1)

Religious conflict is completely unnecessary and a misuse of religion, whose consequences abound in polity. Ody (2000) notes that:

$[T]$ he over-all negative implication of these is that we unleash unnecessary havoc on ourselves as misuse of religion becomes a boomerang that falls back to crush both the victim and the victor, the guilty and the innocent. (p. 13)

It is not difficult to prosecute religious crisis in Nigeria, as the battle axes are readily available. Certainly, according to Idoko (n.y.):

Unemployed youths especially the Almajiris are used as war machines to carry out violence in the northern part of the country. They receive their impetus from a promise of a ticket to heaven, should they die in the process. In Nigeria today, positive gains of pluralism are being frustrated because of fanatical tendencies among the various religious groups. (p. 1)

Knitter (ed. 2005) is very much aware of the functional and dysfunctional nature of religion, that is, he knows very well that religion could be both a source of discord and a form of conflict resolution. It is in recognition of this that he, in spite of his advocacy for religious pluralism, has warned that religion should never be used as an excuse to cause social disharmony. In fact, Knitter (ed. 2005) seems to have believed that the value or religious pluralism by way of inter-faith dialogue manifests itself better in the face of fundamentalisminduced crises. Thus, for Knitter (ed. 2005):

Religious believers cannot stand aside when people are murdered in the name of God or a sacred cause. When religion is invoked as a justification for conflict, religious voices must be raised in protest. We must withhold the role of sanctity when it is sought as a check for violence and bloodshed. If faith is enlisted in the cause of war, there must be an equal and opposite counter-voice in the name of peace. If religion is not part of the solution, it will certainly be part of the problem. (p. 1)
Thus, 'religions contributed to the underdevelopment and destruction of human society in Nigeria' (Ugwuonah 2013). None of the adherents of the three religions in Nigeria could be exonerated from its misuse. However, one has been outstandingly violent in nature. Therefore, Ody (2000) wanted to know which religion is causing so much pain for Nigeria. Of course, Islam has bred many terrorist groups in Nigeria; such groups include Izala, Maitatsine, Shiite Islamic sects and Boko Haram. These groups seem to have link with other Islamic terrorist groups of the world, such as Al-Qaeda in Pakistan, Taliban in Afghanistan, Hamas in Palestine, Hezbollah in Lebanon, Al-shabab in Somalia and so on.

The emergence of these terrorist groups has unleashed heavy calamity in the world. In Nigeria, the menace has been so devastating and uncontrollable that not even the effort of commander in chief has had any serious impact. The Middle Belt region has continued to boil with rage; recently, such crisis erupted in Kaduna, and 'at least 55 people were confirmed killed in the fresh violence' (Omonobi \& Erunke 2018). In fact, 'since the late 1980s, Kaduna has suffered many episodes of inter-communal carnage and it is now a city sharply divided along religious lines (Daily Trust 2018). According to Idoko (2018):

The crisis which many suggest has a religious undertone spread to other parts of the state on Sunday leading to the imposition of a 24-hour curfew on Kaduna metropolis and its environs. The violence comes weeks after a similar incident occurred in neighbouring Plateau State, which led to scores reported dead. (p. 1)

Shortly after the attack on Christian community in Plateau state, the Miyetti Allah Cattle Breeders Association of Nigeria (MACBAN) described the attacks as an act of retaliation over the killing of 300 cows belonging to its members (Murray 2017). Nyitsse (2018:44) explained that it was a grand plan 'to destroy or completely obliterate Christianity. The herdsmen are used as arrow-heads to cause injury and penetrate before the rest of the body will enter'.

In these religious crises and indeed the previous ones in the North, both federal and state governments have been accused for their partiality in these affairs. Muslim politicians do not want to recognise the constitution of the Federal Republic of Nigeria which states that Nigeria is a secular state and allows freedom of worship. This is evident in a number of government policies, for instance, government restrictions placed on Christian evangelism without, in the opinion of the Christian Association of Nigeria (CAN), placing similar restrictions on Islam. As the CAN Northern Zone (1988) puts it:

Our schools and colleges have been taken over by government and yet we see schools and colleges established under the umbrella of another religion [that is, Islam] being sponsored and entirely financed and administered by government; we have been denied access to the use of the [sic] electronic media in certain parts of the country and yet another religion has the monopoly of rendering a near-24-hour religious broadcast in the same areas; some states have deliberately refused to accept and recognize the growing population of Christians in the states, 
thus depriving the Christians not only of their rights but also questioning their claim to being indigenes of such states as claim to be religiously homogeneous. (p. 42)

To treat an indigene with disdain simply because of his or her religious affiliation is a breach of Nigerian constitution and a clear evidence of religious intolerance. Just as Asadu (2018:13) has observed: 'The use of religion as identity and the outright intolerance of other religion by the extremists is the cause of disunity in Nigeria'. Interestingly, Islam which claims to be the religion of peace has no tolerance for non-Muslims. It makes deliberate efforts to deny Christianity fundamental right of freedom of worship. There is an evidence of inhuman treatment meted out to non-Muslims in the North. For instance, Adefila (2000), a permanent secretary in Kwara state, was compulsorily retired without due process for preaching the gospel at Kabba on 'Light and Darkness' at a 3-day revival in January 1980. Hence, Murray (2017), a British think-tank director, wrote an article entitled, 'Who will protect Nigeria's Northern Christians?' Murray (2017) asserted that 'Northern Christians are enduring terrible suffering at the hands of Muslims and accused various groups of actively colluding with the herdsmen or of simply ignoring their embattled victims'.

Furthermore, on the inordinate polices of the government, it was observed by the CAN (1988) that:

These restrictions also include the bureaucratic difficulties Christians experience before they can get land to build churches in the North. The following account by the Anglican Bishop of Kaduna, T.E. Ogbonyomi, is typical of such experiences. On the 5th of March 1986, he applied for land to erect a church for the Protestant community at the Government Girls Secondary School, Kawo, Kaduna, formerly owned by his Diocese. By the 11th of April 1987, he had not received even 'the courtesy of acknowledging the receipt of [his application], not to [mention] taking any worthy action on it', despite his sending a reminder on the 28 May 1986. (p. 1)

The unreasonable restrictions are unabated even under current administration. For instance, in 2016, the incumbent governor of Kaduna state, Mallam Nasir El Rufai, banned churches from holding outdoor programmes; they were only allowed to operate within the church premises. To legalise his action, he sent an executive bill to the State House of Assembly for consideration and possible passage into law. The bill was much more than for outdoor programmes, because had the bill sailed through it would have become:

$[A] n$ offence for any person to preach without a license; play a religious cassette or use a loud speaker for religious purposes after $8 \mathrm{pm}$ in public places; use a loud speaker for religious purposes other than inside a mosque or church and the surrounding area outside the stipulated prayer times; abuse religious books; incite disturbances of the public peace; abuse or use any derogatory term in describing any religion; or carry weapons of any description, whether concealed or not, in places of worship or to any other place with a view to causing religious disturbance. (Shiklam 2016:1)
In fairness to the governor, one may say that his action was not specifically geared towards Christianity, but may only be an attempt to regulate the on-going religious abuse in the state. But by implication, it tends to mean that preachers of the gospel are to be determined by the governor, a nonChristian, who is ignorant of biblical hermeneutics and textual exegeses. Besides, banning vigils, use of horn speakers by churches, disallowing Christian music in vehicles, parks, markets or shops, and opposition to invite preachers from outside the state without clearance from the government were a ploy to curtail the spread of church. After all, in the same state, Muslims hang their horn speakers on every nook and cranny with which they call for prayers five times daily. This is a depiction of religious intolerance masterminded by the Muslim political class. Prof. Femi Ehinmidu was quoted to have reacted to the governor's action by insisting that 'the Bible commands Christians in the book of Mark 16: 15 to go into the entire world and preach the gospel to every creature. This is the foundation and life wire of the Christian religion ... Taking away our rights to preach and evangelise is telling us not to practise our religion as we are commanded by the Lord Jesus Christ' (Shiklam 2016:n.p).

It is, therefore, not surprising that the government has been accused of being an accomplice in the recent crises in Kaduna. Speaking on this matter at the floor of the Senate, senator Danjuma Lar, representing Southern Kaduna, blamed the crisis on the government of Kaduna state governor, who, he said, travels out of state without appointing someone to act on his behalf. He further accused El Rufai for allowing attacks on Christians in Southern Kaduna because they did not vote for him. Indeed, the extent of religious crisis in Nigeria is alarming. In the past, Mason (1985) has lamented the situation, thus:

A major challenge that has confronted the country over the years is that of religious violence between Muslims and Christians. The relationship between the two has been one of mistrust and suspicion. This has led to incessant religious crises. This is as a result of their different perceptions of the ideal society and the conflicting strategies of power and posturing which has made the ideological gap impossible. (pp. 44-45)

Also, the Taraba state governor, Darius Ishaku, asserted that '264 persons were confirmed dead and property estimated at billions of naira destroyed in the $2017 / 2018$ crisis on the Mambilla Plateau in Sadauna local government area' (Ishaku 2018:1). It is unfortunate that some Nigerians allowed religion to play its divisive role whose side effects are dangerous and fatal.

\section{Implication of religious pluralism for the (Christian) church}

The church had made impressive stride in improving the destinies of Nigerian citizens through the provisions of quality education, which, to a great extent, has transformed the Nigerian society; free gospel messages that have moulded the character of myriad of Nigerian citizens; and through the provision of reliable healthcare services that have saved 
many miserable indisposed people. Unfortunately, rewards for Christians' lofty contributions have been ruthless tortures, senseless killings and wanton destruction of their properties by jihadists. As has been mentioned earlier, at several occasions the government had collaborated with jihadists to frustrate church's efforts. Government confiscated properties belonging to the church by way of forceful takeover of mission schools and lands and expelling of expatriate missionaries in Nigeria immediately after the civil war. The worst is that successive federal governments since independence have not been fair to the church. Government has not sincerely protected Christians from these brutalities.

\section{Obviously, in the words of Onyeidu (1999):}

$[R]$ eligion is handicapped where there is no freedom of [sic] worship or where the state is anti-religion. Religion needs freedom to operate effectively, especially in a multi-religious nation like Nigeria. (p. 21)

Normally, religious pluralism gives equal opportunities to different religions to function in a particular state. Thus, worshipers have the freedom to worship in their own liturgical way, without encroaching on the rights of other religion's worshipers of different faith. Every religious being is at liberty to worship in its way is guaranteed. Therefore, no force should be used in making converts, rather religious institutions must operate flexibly so that religious adherents could decide for themselves to practice religion of their choice.

The fact that Nigeria is a pluralistic society is the cause to believe that religious pluralism if given its proper place in Nigeria could avert inordinate and incessant religious conflicts. This should, however, not to be taken as a simplistic solution, given the fact that there is propensity for constant violence in a society where religious autonomy and freedom are recognised. In a pluralistic society, there would always be a potential for violence if religions claim the right to do mission work amongst others. This brings to the fore the imperativeness of Gandhi's assertion that education is incomplete without religion. It is through education and inter-faith dialogue that adherents would be made to understand that all religions have a common mission; hence, all religions are the same. Christians and indeed adherents of other religions in Nigeria are advised to educate their members on the need to imbibe good virtues of religion and religious diversity whilst taking a series of expedient measures to improve their religion's fervour to serve humanity.

\section{Negative implications of religious pluralism}

The negative implication of religious pluralism is its flexibility, which has the tendency to encouraging syncretism. Certainly, in a pluralistic society, an individual could be trapped in two divergent religious views, which amounts to a pretentious practice of religious belief, which is averred by
Christianity. A scholar has attempted to establish this fact in the following manner:

Religious liberty guarantees that multiple religions can worship peaceably, and Christians appreciate such liberty, as it allows for open worship of God. In contrast, religious pluralism teaches that multiple religions are true or equally valid, something the Bible clearly refutes. We encourage religious liberty, but at the same time we communicate the Bible's teaching of 'one God and one mediator between God and men, the man Christ Jesus' (1 Tim 2:5). (Got Questions 2020:1)

In view of these explanations, it therefore becomes clear that pluralism if not properly checked leads to religious ambivalence. When that happens, it becomes a threat to Christian theology as it negates the teaching that 'there is salvation in no one else, for there is no other name under heaven given amongst men by which, we must be saved' (Ac 4:12). For example, in Europe and America where pluralism has been entrenched, significant numbers of people who profess Christianity have begun to jettison the claim that 'Jesus is the way' by which one can go to God (Jn 14:6). Thus, there has been agitation for rewriting of the Bible so that such a clause should be changed to read as 'Jesus is a way'. This is one of the things Christianity would always contend with in a pluralistic society. If Christianity is overwhelmed by the pluralistic view, it becomes mere superficial and incapable of transforming humanity. This was further elucidated by Erdel (2019):

The ideology of religious pluralism has long been a fact in the West, even during the so-called age of faith when Christendom became the dominant socio-political force. The evils of Christendom are well known. Church membership became one's socio-cultural birthright, rather than a sign of genuine religious commitment, thereby leading to cheap race, unreflective faith, and nominal Christianity. (p. 1)

It is, therefore, not out of place to state that religious pluralism is like a two-edged sword. It could make or mar the Christian faith. An ardent believer in pluralism is betwixt and between; the best he can be is a nominal member.

There is a contradiction about pluralism. Pluralism creates opportunity for religions to coexist peacefully. If a religion such as Christianity claims that it has the only means to salvation and must convert all others through mission work, it changes the pluralist model, to which Christianity claims to subscribe, to exclusivism, which denies pluralism. Thus, although Christians and adherents of other religions purportedly subscribe to pluralism, they encourage exclusivism by way of their missionary works, and this raises the following fundamental question: How does a religion continue to do mission work (exclusivism) when it acknowledges the autonomy (pluralism) of all religions?

Another negative implication of religious pluralism is that it has the propensity to undermine national security. In a recent article, Levy (2018) has given the insinuation that it is mainly governments with autocratic and authoritarian bent that do everything to suppress religious pluralism. In an attempt to 
qualify this claim, he made reference to governments across the post-Soviet terrain. In his words:

Since the late 1990s, governments across the post-Soviet space have redefined freedom of conscience as freedom from the influence of 'non-traditional', 'destructive' and 'extremist' religious groups. These groups range from Evangelical Christians and Jehovah's Witnesses, to the Chinese spiritual movement Falun Gong and the Islamic missionary movement Tablighi Jamaat. Governments have ... drastically curtailed the rights of the latter to practise and proselytise openly. (p. 243)

Levy (2018) further observes that:

[T]he Parliament of Kyrgyzstan passed a resolution stating that the expansion of 'non-traditional religions' complicates the religious situation in the republic and requires a serious approach and direct involvement of the state. (p. 248)

In a related development, Levy (2018:248) further quotes the head of Kazakhstan's Agency for Religious Affairs as saying in an interview that 'the transition of people from traditional confessions to non-traditional ones poses a threat to the unity of the nation and the state'. It follows from Levy's above observations that some states which are against religious pluralism do so because of security. They see the pluralist model as a fertile ground for breeding extremists and fundamentalists that may at the long run pose threat to the unity of the state.

\section{Recommendation}

This article recommends that beyond verbally professing religious pluralism, churches in Nigeria should focus their efforts more on teaching their members how to imbibe the virtues of pluralism and de-emphasise missionary campaign.

Equal treatment to adherents of all religions must be provided by the government, given the fact that the constitution of the Federal Republic of Nigeria provides for freedom of worship. All religions should be allowed to grow and develop without government interference.

Government must remorsefully return to the church all its properties, which the government took forcefully. Such confiscated properties include lands, mission schools and health institutions. Government must also allot new lands to church for developmental projects, as this would enable church to work for maximum impartation of Nigerian citizens.

Government must dutiful protect lives and properties of all Nigerians, particularly the worshipers. It should endeavour to bring the perpetrators of religious intolerance to book. It must also pay adequate compensations to the victims of religious intolerance.

Religious war is worse than a civil war and no sensible government would allow its country to experience it. The best way to avoid it is to give all religions equal rights to exist and stop religious extremists from attacking the people of other faiths, as this would throw the country into religious war. After all, no religion has a monopoly to indulge in violence.

\section{Conclusion}

For the fact that our society itself is a plural society, religious pluralism is unavoidable. Followers of any given religion must of necessity learn how to live with the adherents of other religions, given the fact that living with them is unavoidable. This brings us to one far-reaching implication of embracing the model of religious pluralism, that is, the teachings of all religions have to be relativised if members of these religions are to be accepted by one another. It is a bitter truth that has to be accepted that by accepting pluralism we are taking the position that none of us has the final Truth. The researchers do not state that adherents of one religion should allow their relationships with another, or other religions change their own religions' core values. On the contrary, the researchers only convey that once they acknowledge the reality of religious pluralism, they must be prepared to take it for what it is. After all, pluralism must be seen as a doubleedged sword with the propensity to foster dialogue and understanding as well as confuse whosoever embraces it.

Whilst we are aware that no religion could in reality operate without some form of missionary work, but we view that missionary campaign should not be emphasised as doing so does not seem to correlate with the advocacy of religious tolerance. It has to be noted that whilst religious pluralism calls for peace, this article posits that the reality of religious pluralism is an acceptance of religious autonomy, which it thinks could be manipulated in a negative direction. Having said this, the article submits that the onus lies on the governments of circular states to devise more stringent regulatory measures that ensure peaceful coexistence amongst various religions in their respective states. Therefore, whilst the article admits the positive virtues of peaceful coexistence implied in religious pluralism, it nevertheless does not advocate that missionary work of one religion becomes part of relationship towards other religions.

\section{Acknowledgements}

The authors also wish to thank Mr Favour Uroko for his technical assistance towards the success of this work.

\section{Competing interests}

The authors have declared that no competing interests exist.

\section{Authors' contributions}

G.C.A. conceptualised and carried out the research; N.A. assisted with important literature, whilst B.C.D. assisted in making the manuscript better.

\section{Ethical consideration}

This article followed all ethical standards for a research without direct contact with human or animal subjects. 


\section{Funding information}

This research received no specific grant from any funding agency in the public, commercial or not-for-profit sectors.

\section{Data availability statement}

Data sharing is not applicable to this article as no new data were created or analysed in this study.

\section{Disclaimer}

The views and opinions expressed in this article are those of the authors and do not necessarily reflect the official policy or position of any affiliated agency of the authors.

\section{References}

Adefila, S.A., 2000, Tithing a gateway into divine abundance, INDEMAC Publishers, Illorin.

Anyacho, E.O., 2005, Essential themes in the study of religion, NigerLink Printing and Publishing, Obudu.

Asadu, G.C., 2015, Ibagwa-Aka Ozuzikoko in Church history: Origen, growth and impact 1914-2014, Great Ap Express Publisher Ltd., Nsukka.

Asadu, G.C., 2018, 'Inflammatory language: A massive inducement to ethno-religious conflict in Nigeria', Sapiential Global Journal of Arts, Humanities and Development Studies (SGOJAHDS) 1(1).

Boer, H., 1976, A short history of the early church, Daystar Press, Ibadan.

Christian Association of Nigeria (CAN) Northern Zone, 1988, Leadership in Nigeria (to date): An analysis, CAN Publicity, Kaduna.

Deshpande, N.B., 2018, Understanding the concept of religious pluralism with examples, viewed 27 December 2019, from https://spiritualray.com/under standing-concept-of-religious-pluralism-with-examples.

Domenic, M., 2007, Theology of religions: Pluralism, inclusivism, exclusivism, viewed 18 October 2018, from https://www.google.com/search?q=Domenic+Marbanian $\mathrm{g}+$ Theology+Of+Religions $\% 3 \mathrm{~A}+$ Pluralism $\% 2 \mathrm{C}+$ Inclusivism $\% 2 \mathrm{C}+$ Exclusivism\&ie $=u$ $\mathrm{tf}-8$ \&oe=utf-\&client=firefoxb-ab.

Daily Trust, 2018, Editorial: A week of crises in Kaduna, viewed 18 October 2019, from https://www.dailytrust.com.ng/a-week-of-crises-in-kaduna.html.

Erdel, T.P., 2019. Theological education and religious pluralism, viewed 20 August 2019, from https://biblicalstudies.org.uk/pdf/binah/01_034.pdf.

Got Questions, 2020, What is religious pluralism?, viewed 30 March 2020, from https://www.gotquestions.org/religious-pluralism.html.

Harris, S., 2005, The end of faith: Religion, terror, and the future of reason, W.W. Norton \& Company, New York, NY.
Hick, J., 2005, 'The next step beyond dialogue', in P.F. Knitter (ed.), The myth of religious superiority: Multifaith exploration of religious pluralism, Orbis Books, Maryknoll, New York, NY.

Idakpo, S., n.d., Religious pluralism in Nigeria: Implications for national integration, viewed 25 September 2018, from www.academicexcellencesociety.com.

Idoko, S., 2018. Nigeria: Buhari, Saraki, others react to Kaduna Violence, Curfew, Premium Times, October 21, viewed 28 December 2019, from https://allafrica. com/stories/201810220015.html.

Idowu, F.J., 2009, 'Building peace bridges: Which mode, what pattern, what approach', New Nigerian 15, 8.

Ireoba, P.O., 2008, 'The saviour that we need', Trinity Magazine 4, 1.

Ishaku, D., 2018, 264 persons died in Mambilla Plateau crisis, viewed 18 October 2018, from http://thenationonlineng.net/264-persons-died-in-mambilla-plateaucrisis-says-ishaku/.

Knitter, P.F. (ed.), 2005, The myth of religious superiority: Multifaith explorations of religious pluralism, Orbis Books, Maryknoll, New York, NY.

Levy, D., 2018. 'The impulse to orthodoxy: Why illiberal democracies treat religious pluralism as a threat', Religion, State \& Society 46(3), 243-265. https://doi.org/10. pluralism as a threat', Religion, S
$1080 / 09637494.2018 .1492841$

Mason, T.F., 1985, 'Religion and the new Nigeria: Current misconceptions and modest proposals', Jos Bulletin of Religion 1, 44-45.

Mbiti, J.S., 1969, African religions \& philosophy, Heinemann Educational Publishers, Oxford.

Murray, D., 2017, Who will protect Nigeria's Northern Christians?, viewed 21 November 2019, from https://www.vanguardngr.com/2017/06/re-willprotect-nigerias-northern-christians/.

Nyitsse, M.G.F., 2018, Presidential Address delivered at the first Session of the fourth Synod of the Diocese of Gboko held at the Cathedral Church of St. Mark, Gboko Synod of the
Central.

Objantoro, E., 2018, 'Religious pluralism and Christian responses', Evangelikal: Jurnal Teologi Injili dan Pembinaan Warga Jemaat 2(1), 1-9. https://doi.org/10.46445/ ejti.v2i1.94

Ody, J.O., 2000, The Sharia and rest of use, Snaap Press Ltd, Enugu.

Oka, U.J., 1996, 'Religious pluralism and conflict in Nigeria', Anglican Magazine 1(3).

Omonobi, K. \& Erunke, J., 2018, Kaduna crisis: El-Rufai imposes 24-hour curfew on Kaduna metropolis, viewed 18 October 2019, from https://www.vanguardngr.com/2018/10/ kaduna-crisis-el-rufai-imposes-24-hour-curfew-on-kaduna-metropolis/.

Onunwa, U., 1990, Studies in Igbo traditional religion, Uruowulu-Obosi, Pacific Publishers, Anambara.

Onyeidu, S.O., 1999, The phenomenology of religion, Esy-Quality Press and Series Publication, Enugu.

Seshagiri, R.K.L., 2005, 'Mahatma Gandhi: A prophet of pluralism', in P.F. Knitter (ed.), The myth of religious superiority: Multifaith exploration of Religious Pluralism Orbis Books, Maryknoll, New York, NY.

Shiklam, J., 2016, Kaduna: El-Rufai's Controversial Religious Bill, viewed 03 April 2016 , from https://www.thisdaylive.com/index.php/2016/04/03/kaduna-el-rufais-contro versial-religious-bill/.

Ugwu, C.O.T. \& Ugwueye, L.E., 2004, African traditional religion: Prolegomenon, Merit International Publication

Ugwuonah, S.I., 2013, 'Is religion truly a beacon for solutions to Nigeria's problems?', Logos Magazine, a Publication of the National Association of Students of Religion and Cultural Studies, University of Nigeria, Nsukka, vol. 3 